\title{
Winning and losing rural localities of the post-socialist economic restructuring: case study of Czechia
}

\author{
VLADAN HRUŠK ${ }^{1}$ and JAN PÍŠA ${ }^{2}$
}

\begin{abstract}
Retreat from socialism at the turn of the 1980s and 1990s conditioned significant social, economic and environmental changes for former socialist countries. Transformation from the centrally planned economy under the authoritative regime to market economy and democratic system re-structured also economies of rural areas. As a result, the conversion to capitalism constructed successful rural localities enjoying growing wealth whereas, on the other hand, other rural localities struggle with high unemployment, low incomes and following emigration of qualified people. This paper, on the example of rural space in Czechia, analyses time-spatial development of number of jobs on local level and reveals main factors which have been constructing economically successful and unsuccessful rural localities in the post-socialist period. Based on this, six model responses to post-socialist economic rural restructuring are identified: globally integrated service-oriented, entrepreneurial, industrialised, post-productivist, deindustrialised and post-mining and energy-producing rural localities.
\end{abstract}

Keywords: post-socialism, economy, restructuring, rural, Czechia

\section{Introduction}

Rural space has been for a long time perceived as something stable and unchangeable which (un)successfully avoids modernisation impulses in comparison to dynamically growing urban areas. However, this dichotomy doesn't seem to be legitimated as also rural space constantly undergoes extensive transformations (Woods, M. 2005, 30). The switch from the centrally planned to market economies is the most important transformation which has been discussed since the 1990s in the context of rural areas of Central and Eastern European (CEE) countries. Basic system, institutional and structural changes in national economies (SYNEK, M. 2004) accompanied such transformation and significantly influenced fortunes of rural localities of these countries (e.g. Swain, N. 1996; Turnock, D. 1998, 2000; Rey, V. and Bachvarov, M. 1998; Dingsdale, A. 2002; Brown, D.L. 2002; Gorlach, K. et al. 2008; PospĚch, P. 2014; Jucu, I.S. 2016). Such changes had a large impact not only on agriculture (as it was dominantly stressed in many studies from the 1990s) but also other economic activities located in rural space such as mining, energy production or manufacturing. Yet the level of success or failure of rural economic restructuring has been spatially very unequal - some of the rural localities have reported inflow of new economic activities during the restructuring period whereas other fall into the vicious circles of rural poverty and social exclusion. As a result, rural Europe could be characterised by a new mosaic of rural regions with winners, in-betweens and losers (Terluin, I.J. 2003).

\footnotetext{
${ }^{1}$ Jan Evangelista Purkyně University in Ústí nad Labem, Faculty of Science, Department of Geography, České mládeže 8, 40096, Ústí nad Labem, Czechia. Corresponding author's e-mail: vladan.hruska@ujep.cz

2 Jan Evangelista Purkyně University in Ústí nad Labem, Faculty of Science, Department of Geography, České mládeže 8, 40096, Ústí nad Labem, Czechia. E-mail: jan.pisa@ujep.cz
} 
Many authors attempted to focus on this growing spatial differentiation and suggested various typologies of post-socialist rural localities. However, these attempts are very general - such as empirical typologies of rural space on the European level based on NUTS III regions (e.g. BAllas, D. et al. 2003; BAUM, S. et al. 2004; Copus, A.K. et al. 2006; Scholz, J. 2009; Weingarten, P. et al. 2010) and national typologies of rural space (with focus on the CEE countries e.g. BELuszKy, P. and Sikos, T.T. 2008; Bogdanov, D. et al. 2008; Perlín, R. et al. 2010; Bański, J. and Mazur, M. 2016; Perger, É. et al. 2016). These typologies are usually holistic - focusing on each sphere of rural life, and based on a mix of statistical data. Therefore, their results are hardly transferable into other spatial contexts (contrary to rather theoretical typologies of rural economies which are discussed in the next part of the paper). Also, they dominantly link the post-socialist economic restructuring with agricultural restructuring and stress the processes which deteriorated economic conditions in rural localities but do not focus on processes which enabled economic growth. Notable exception from this point of view is the typology of Czech non-metropolitan regions by ŽENKA, J. et al. (2017) who analysed economic profile of Czech regions located out of the metropolitan areas. Their typology identifies spatial variations in key factors, actors and mechanisms of development. However, in this analysis also urban areas were included therefore the results do not represent exclusively rural areas. Moreover, if these typologies (apart from the typology by ŽENKA, J. et al. 2017) focus on economic development, they are based on sectoral occupation of rural inhabitants with no regards to the fact where their employment is really situated - it means they do not analyse the structure of jobs which are really present in rural areas. As such, these typologies failed to discover what really happened during the post-socialist decades in rural areas.

Therefore, for a better understanding of differentiation of post-socialist rural restructuring (1) more detailed analysis of rural economies (based on very small spatial units) is needed and (2) this analysis must be focused on employment opportunities which are really present in rural areas - it is better to examine economic structure of rural localities based on jobs located there (contrary to employment which is ascribed to rural people but very often practised in urban areas). Within our paper, we introduce the results of such analysis on the example of the post-socialist Czechia. Based on this, first, we identify rural localities with the best and worst economic performance (measured by the number of jobs) during the post-socialist period. Second, after a close look on these winners and losers we indicate distinct processes which have dominantly formed the way of the post-socialist rural economic restructuring in rural Czechia.

\section{Rural localities and uneven economic dynamics}

At the beginning of the theoretical discussion, we would like to stress the key spatial concept for the following analysis - concept of (rural) localities. Although Hoggart, K. (1990) and other scholars before the onset of postmodern approaches in rural geography refused the existence of a specific 'rural' locality and suggested to 'do away with rural', the term 'rural locality' is acknowledged by rural scholars and finds frequent use in contemporary rural studies. Its popularity has increased since its integration with definition of rural as a social construction. At the beginning of locality debates there was a question, to which extent are distinctive places results of local and non-local structuring processes. The structuring power of external processes of regional, national and global scale has been acknowledged and the discussion turned to the point what are the capacities of local actors to transform the external influences in order to avoid their negative impacts and generate benefits for a given local community. Reflecting this, the locality is defined as active, semi-autonomous units (Murdoch, J. and Marsden, T. 1995) with a relative openness to external relations. As 
such, to a limited extent it also gives an opportunity to rural actors to influence the destiny of their own locality (Murdoch, J. and MarsDEN, T. 1994). On the other hand, Moseley, J.M. (2003) argues that institutional capacities of local communities are still only limitedly able to influence processes from the national or even global level

The concept of locality has been developed in order to grasp the increasingly diverse character of (rural) space as the consequence of intensive penetration of neo-liberal principles into spatial regulation and planning. Many rural scholars (e.g. Murdoch, J. et al. 2003; Halfacree, K. 2004; Hodge, I. and Monk, S. 2004; Holmes, J. 2006; Brunori, G. and Rossi, A. 2007; VAn Der Ploeg, J.D. et al. 2008) recognise growing differentiation of rural space and suggest specific models of rural localities which differ from each other based on their social, economic, cultural, environmental and institutional profile. In the next paragraphs, we will focus only on typologies which more deeply analyse diverse economic milieus of rural localities. Typologies of farming systems were excluded (e.g. VAN der Ploeg, J.D. et al. 2008; Wilson, G. 2010) as we disagree with arguments which ascribe the central role in rural development to agriculture.

Marini, M. and Mooney, P. (2006) developed typology purely focused on rural economies and suggest three distinctive types. First, rent-seeking economy is localised in rather peripheral rural areas whose economies are mostly based on rather large farms and firms in mining and extraction. These actors control high proportion of local land rent and like this they don't have special motivation for further investment in local development. Second, dependent economies are based on attraction of external sources (both of public and private origin) which expose them to a higher risk in the periods of fiscal austerity (decline of subventions) or economic downturn (outflow of foreign direct investment). On the other hand, third, entrepreneurial economies are based on valorisation of local assets by local enterprises. As such, in comparison of these three types, they are considered as the most resilient.
Woods, M. (2013) who engages with the impact of globalisation processes on rural localities suggests a typology of specific responses to these processes. He defines 9 modes of engagement more or less related to the economic dimension of globalisation process. Global resource providers are rural localities rich in mineral and energy resources tightly integrated into global capital and markets. Branch plant economies have been dominantly formed through the urban-rural shift in manufacturing driven by FDI since 1980s or 1990s. Super-productivist farmers focus on large-scale, industrial and often export-oriented agricultural production. Global playgrounds are structured by amenity immigration, growing consumption demand for rural space and related services. Niche innovators are based on highly innovative companies or their cluster which use either local endogenous potential or focus on high-tech or service industries. Trans-border networkers are localities who use their location with cross-border potential and offers special kind of assets (especially cheaper labour and services). Economies of global conservators are limited due to their location in national parks or UNESCO biosphere reservations. Re-localizers concentrate on intensification of local circuits of value in agri-food system or via public procurement etc. Structurally marginalised regions are regions which are not able to use the positive potential of the globalization process.

Introduced typologies more or less consider the proximity of given rural localities to urban centres as an important factor of rural differentiation. From the economic point of view, it seems to be crucial. However, we can find some counter-tendencies when discussing the economic potential of rural localities based on their position on the urban-rural continuum. Burger, M.J. et al. (2015) focus on presence of cultural amenities and discuss the concepts of 'borrowed size' (introduced by Alonso, W. 1973) and 'agglomeration shadows' which typically occur in suburban rural localities. Such localities enjoy 'borrowed size' effects as they host functions which were traditionally located 
in urban centres and that's the reason why the functional importance of these localities largely exceeds its population importance. On the other hand, the concept of 'agglomeration shadows' is opposed to the former. In their later publication (MeIJeRs, E.J. and Burger, M.J. 2017) they carefully scrutinize the term 'borrowed size' and complement it with terms 'borrowed function/performance' in order to cover the gaps related to the term 'size'. In the context of our paper it means that some suburban rural localities can evidence over-average number of jobs (performance) or service/cultural amenities (function), whereas other localities in similar locations dispose with low number of jobs/less services and high level of work and leisure out-commuting to the neighbouring urban centre.

During the 1980s and 1990s British scholars in the context of rural areas reported urbanrural shift in business activity and employment - first in manufacturing (e.g. KEEBLE, D.E. 1980; Fothergill, S. and Gudgin, G. 1982; NorTh, D. 1998), later also in the service sector (KeEble, D.E. and Tyler, P. 1995). Within this shift, increased attractiveness of rural areas for relocation of businesses and employment opportunities has been recognized. Most importantly, in some time spans remote rural areas evidenced more dynamic economic development than accessible rural areas (Keeble, D.E. and Tyler, P. 1995). Rural scholars argue that this shift was partly caused by the immigration of former urban inhabitants usually well-endowed with entrepreneurial skills, knowledge, and creativity (ATTERTON, J. et al. 2012) or human, social, and financial capital (GKartzios, M. and Scotт, M. 2014). Anyway, the economic activity of rural entrepreneurs is not isolated within the rural space, instead they employ extra-regional linkages in order to gain knowledge and access to large markets located in urban areas. Therefore, when considering rural entrepreneurship, it is necessary to consider also the urban dimension of everyday business activities of rural people (MAYER, H. et al. 2016).

\section{Identifying winners and losers of rural economies: data and methods}

Our methodological approach has four important stages:

1. rural municipalities were defined and aggregated into larger spatial units;

2. indicator of number of jobs was quantified;

3. rural winners and losers were identified;

4. economic profile and history of these selected localities were analysed.

First, when analysing larger spatial units, typically statistical (or descriptive by Halfacree, K.H. 1993) definitions of rural space are used. Based on this, a measurable indicator which defines the rurality of a given spatial unit must be determined. For our purposes we have chosen the indicator of population size which was applied on the municipality level (Local Administrative Unit). In Czechia the population size of 3,000 is usually used as a threshold value for identification of rural/urban municipality (such definition was used e.g. by Perlín, R. et al. 2010; Chromý, P. et al. 2011; Bernard, J. 2012) despite the existence of rural municipalities (based on their physical structure and architecture) with more than 3,000 inhabitants especially in South and East Moravia. In order to follow more easily the spatial pattern of results - municipalities with population less than 3,000 have been integrated in larger spatial units based on administrative districts of municipalities with authorised municipal authority (obce s pověreným obecním úřadem - OPOÚ) which serve for purposes of state administration in Czechia. In 2011 there were 389 administrative areas of OPOÚ in Czechia and five military areas. But in ten of them there was no rural municipality and therefore they were considered as urban and excluded from the analysis. Finally, 379 administrative areas of OPOÚ were analysed - hereinafter within the text they are referred to as 'rural locality' in compliance with the theoretical discussion above.

Second, indicator of number of jobs has been used for our research of the post-so- 
cialist economic restructuring. As there is no statistical source in Czechia which would present these data on local level, we had to derive the number of jobs from the formula (this formula was used in other Czech studies e.g. by Hampl, M. 2005 and Hampl, M. and Marada, M. 2015):

$$
J_{A}=E A_{A}+E A_{A_{-} \text {in-com }}-E A_{A_{-} \text {out-com }}
$$

where $J_{A}=$ number of jobs in the municipality $A, E A_{A}=$ economic active population of the municipality $A, E A_{A_{-} \text {in-com }}=$ economic active population commuting into the municipality $A$ from other municipalities, $E A_{A_{-o u t-c o m}}=$ economic active population commuting out of the municipality $A$.

Concerning the data availability - they are based on the results of Czech censuses from years 1991, 2001 and 2011 (more recent data are not available as the next census is planned for 2021). Year 1991 doesn't fully demonstrate the beginning of the restructuring period (for example in some agricultural cooperatives the transformation started immediately in 1990), yet this year is still very suitable for the description of the economic situation before the main restructuring processes started (the unemployment rate in 1991 was 2.3 per cent, thus, very close to the full employment typical for the communist era). Year 2001 may transparently describe the situation of Czech economy after the impact of main restructuring processes related to the privatisation process and retreat of the state from the national economy and before the start of the intensive inflow of FDI (at that time the unemployment rate reached 9.3\%). Year 2011 then demonstrates how rural localities adapted to the challenges of post-socialist restructuring including growing global integration of economy (the unemployment rate was 9.8\%).

Indicator of number of jobs has been chosen due to its ability to transparently describe the economic situation of a given locality. Contrary to the (un)employment indicator, it is strictly related to the selected spatial unit and therefore it can better describe the ability of a given locality to sustain or even generate economic growth. Focus on jobs in rural areas is even more important as new jobs creation is a general target of rural development policies for remote rural areas. As FreshwATER argues 'Community may be able to improve the degree of social cohesion, they may be able to develop both their physical infrastructure and the level of human capital, but if jobs do not exist, it is unlikely that the community will survive.' (Freshwater, D. $2000,6)$. Concerning suburban areas, here the call for new jobs is seemingly not as urgent as in remote rural areas due to their accessibility to employment opportunities located in nearby urban centres. However, their presence (matching with qualification of local people) could decrease the over-dimensional traffic flows, congestions and pollution related to the intensive daily work commuting. On the other hand, in our approach this indicator has also some disadvantages. It doesn't say us anything about the quality of such a job and hereby about its contribution to local economic development. From this point of view, these questions cannot be discussed intensively within this paper, however, some insights in the changing number of jobs are revealed by a more detailed examination of rural winners and losers.

As regards the quality of the data from the censuses - results from the Census 2011 are problematical. In comparison with earlier censuses its results were incomplete - the number of commuting person was lower by about 560 thousand than in 2001 (the total number of commuting people in 2001 was 1.70 million in comparison to 1.14 million in 2011), although the number of economic active employed people hadn't changed much (HAMPL, M. and MARAdA, M. 2015). From this reason, authors had to model the missing data (similarly as MulíčEK, O. and MALÝ, J. 2019) in the categories of in-commuting, out-commuting and economic active residents by their proportional distribution based on the known value of residents living in a given municipality.

Third, rural winners and losers were defined as rural localities which until 2011 had created more than 40 per cent jobs or contra- 
ry, lost more than 60 per cent of jobs in comparison with 1991. Based on these threshold values, for 2011 there were 42 rural winners and 25 rural losers (Figure 1).

Last but not least, selected rural winners and losers were examined in detail in order to get information about the structure of local economy, the way of change and key employers both at the end of the socialist period and in the present. Because there is no coherent database of companies or job structure at the end of the socialist period, information was gathered from various sources - websites of relevant municipalities, daily media, older research studies which defined main employers in given rural localities (e.g. HäUfLER, V. 1984) or by a direct contact with representatives of given rural municipalities. There are no data about jobs structure even for present situation but rural winners were at least analysed by the means of the Bisnode Albertina Database (version 2018) which gathers information about businesses including their location and size in terms of employer number. This analysis serves later as an important input for development of model rural localities.

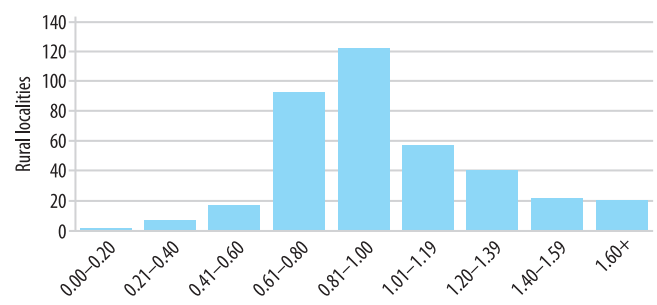

Fig. 1. Frequency of rural localities based on the development of number of jobs in the period 1991-2011. Source: Czech Statistical Office 2011; Federal Statistical Office 1993. Authors' own calculation.

\section{Post-socialist economic restructuring of Czech rural space}

Economic restructuring since the 1990s have produced different spatial impacts, as postsocialist transformation is a complicated pro- cess of institutional changes and behavioural adaptations of people, firms and institutions to new conditions of pluralist democracy and economy regulated by the free-market ideology in which the private companies play the key role. The shift towards market economy marked also the end of levelling tendencies in spatial distribution of sources characteristic for socialist mode of regulation (DostáL, P. 2007). Industrialisation policies of communist regime aimed to balance unequal economic potential among Czechoslovak regions by supporting agricultural and industrial production in smaller towns and rural areas. And indeed, at the end of the socialist period the economic position of small local centres was relatively strong. However, under the newly established capitalist regime, their central position has been weakened or even disappeared due to selective deindustrialisation and tertiarisation processes (MulíčeK, O. and MALÝ, J. 2019). In the new neo-liberal regime Czechia has opened itself to the external world - not only from the physical point of view (more relaxed cross-border regime - removal of 'Iron Curtain' and demilitarisation of Western borderland, implementation of the Schengen Treaty in 2007) but also as regards more fluid and less tangible impacts of trade liberalization and acceptation of European and global values leading to growing global (European) integration of Czech society and economy.

Post-revolution performance of Czech agriculture was influenced by processes of privatization, restitution and transformation of former cooperatives which destabilized agricultural production (e.g. KABRDA, J. and JANČÁK, V. 2007; Нrabáк, J. and KonečnÝ, O. 2018; Žoncová, M. 2018). Moreover, under the influence of the neo-liberalization rhetoric, state subventions decreased rapidly during the period 1989-2000 (VěžNík, A. 2002; Bičír, I. and JANČÁK, V. 2005). This process had a destructive impact especially on farms located in less favoured (sub-)mountain and very often peripheral (MusiL, J. and MüLLER, J. 2008) areas. These areas had been economically lagging already before the socialist period and therefore socialist planners supported local agricultural 
production massively in order to ensure employment for local people. Nevertheless, such policy was at expense of economic productivity, high subsidization, excessive use of chemicals and consequent negative environmental impacts. Therefore, these were just these areas, where calls for elimination of overproduction and more sustainable agricultural practices were implemented leading to rapid job losses in this economic sector. Economic situation of Czech farms started to improve not earlier than with the accession of Czechia into the EU (BAŠEK, V. 2010).

Similarly, mining and manufacturing registered decline in terms of their contribution to national employment and GDP (MuLíčEK, O. and MaLÝ, J. 2019). In socialist countries coal mining had a privileged position as the capital-intensive industries and extensive mode of production of these countries (Pavlínek, P. 2009; Koutský, J. 2011) were based on high amount of inputs including energy. Czechoslovak manufacturing pro- duction during the socialism could be characterised by low labour productivity and associated high costs of production, production of products whose technical standard was lagging behind Western standards (SYNEK, M. 2004). Economies of some rural areas were diversified by old industries (textile, glass and ceramic industry) which dated back to the first waves of industrialization. From this point of view, the situation in Czechia was different than in other CEE countries - Czech rural localities showed high proportion of industrial employment, whereas eastern parts of Poland and Hungary were predominantly focused on agriculture (ŽENKA, J. et al. 2015).

However, growing environmental concerns (PAvlíneK, P. 1998) suppressed during the socialist regime initiated new environmental measures and policies. Their impact was particularly painful in rural areas integrated into old industrial regions of northwest Czechia and Ostrava agglomeration (PavlíneK, P. 1998; KLusáčEK, P. 2005;

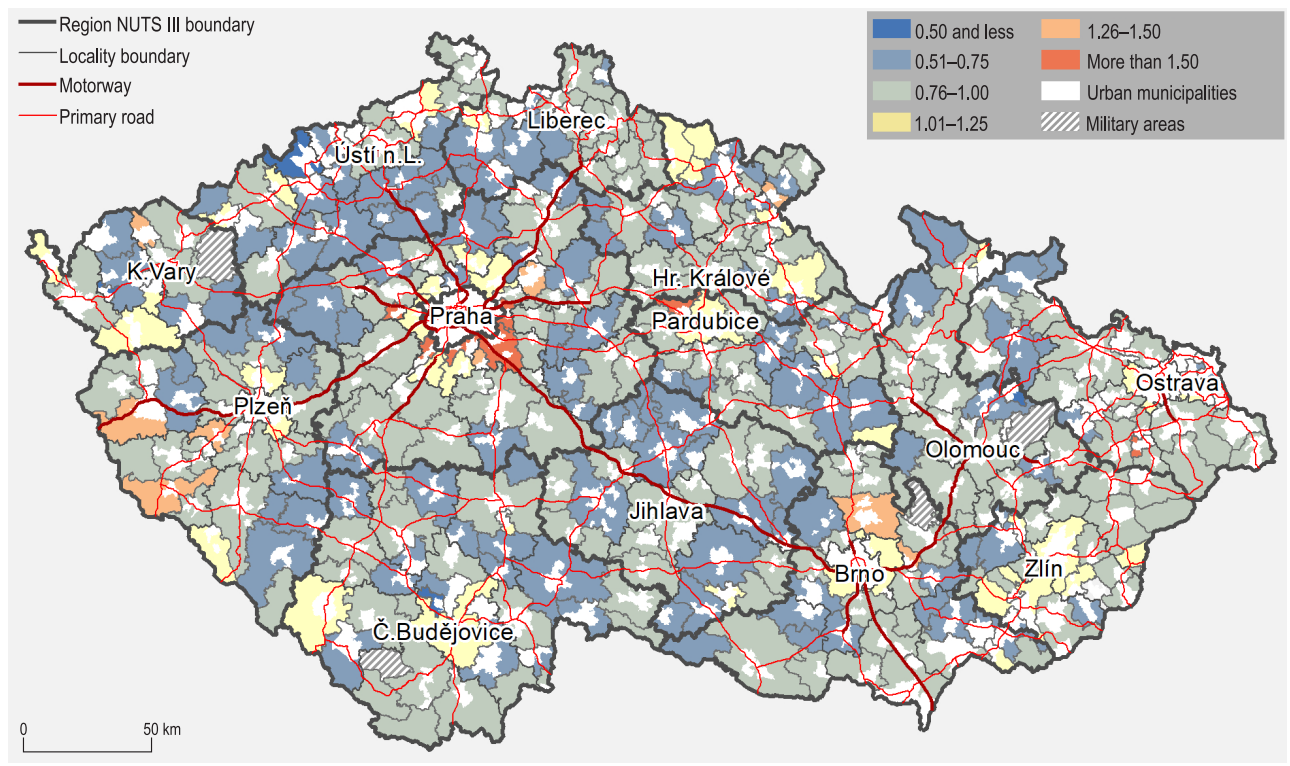

Fig. 2. Change of number of jobs in rural localities of Czechia in the period 1991-2001 (1991=1.00). Source: Federal Statistical Office 1993; Czech Statistical Office 2001; ArcĆR 500. Authors' own calculations. Compiled by the authors. 
Koutský, J. 2011). Apart from them, rural areas dependent on old industries producing low value added products suffered from growing unemployment as these economic industries has been particularly vulnerable under the neo-liberal conditions of globally integrated economy. As a result, during the first decade of rural restructuring massive job loss could be observed in each of the NUTS III regions of Czechia (Figure 2), whereas in rural localities the economic downturn was more serious (in 2001 by $18 \%$ less jobs than in 1991) than in urban localities (job loss by $7 \%$ ).

On the other hand, since the beginning of the 2000s high inflow of foreign direct investment (FDI) to Czechia driven by lower labour costs, skilled and well-educated labour, long manufacturing tradition, strategic geographical position in the EU (since 2004 Czechia is a member state of the EU) and massive state investment incentives has been observed. Koutský, J. (2011) labels this period as a period of organised re-industrialization and from this point of view, also in Czech rural localities some patterns of urban-rural shift in manufacturing might be observed.

FDI of transnational investors have significantly transformed and developed (at least quantitatively) also the service sector. Their intensive development was partly preconditioned by an under-dimensioned service infrastructure from the socialist period (SzCZYRBA, Z. 2000). Since the mid-1990s retail chains from Western Europe discover Czechia as a new destination for investment of profits gained on domestic markets (CoE, N.M. et al. 2013). The Czech retail market got internationalised and concentrated quickly (KUNC, J. et al. 2013) whereas buildings of new supermarkets and hypermarkets and logistics parks intensively transformed landscape of suburban rural localities and commuting patterns within urban agglomerations (MuLÍčEK, O. and MaLÝ, J. 2019). Such suburban rural localities enjoy the 'borrowed performance' (BURGER, M.J. et al. 2015) effects when the number of jobs per capita significantly exceeds the average number in similar localities and sometimes even the number of local economic active population.
On the other hand, the growth of entrepreneurial activity in services (including creative industries) in these localities has been driven also by local factors - entrepreneurial in-migrants (ŽENKA, J. and SLACH, O. 2018; PÍšA, J. and HrušKa, V. 2019). Our additional analyses of entrepreneurial activity per capita in age +15 for year 2017 (Czech Statistical Office 2018c) showed that among the TOP 20 rural localities with highest levels of entrepreneurial activity 15 were located in the Prague metropolitan area and five in Šumava and Krkonoše Mountains with strong recreational function accompanied by relevant services in retail and hospitality. Strong entrepreneurial activity in recreational rural localities is a consequence of growing purchasing power of medium and upper class residents, individual car-ownership and increasing inflow of foreign visitors since the end of 1980s.

New firms both in manufacturing and services generated new employment opportunities especially in peri-urban and well accessible rural areas (Figure 3). In the period 2001-2011 (until the global economic downturn) the growth of employment opportunities was reported in rural areas (by 16\%) whereas in urban areas the number of jobs decreased by 4 per cent. One could argue, that the growth of number of jobs in suburban rural localities is given by the growing population of these areas and their entrepreneurial attitudes. However, if we compare the development of number of jobs and economic active population in rural areas, the former is growing quicker in each of the NUTS III regions apart from the Karlovy Vary Region.

Generally speaking, social and economic processes driving post-socialist restructuring have intensively transformed employment patterns in Czechia. From the rural point of view, rapid loss of jobs was reported in agriculture and mining. On the other hand, deand re-industrialization process had highly unequal spatial distribution. As a result, the industrial employment in Czechia has decreased only slightly since 1990 (Table 1). 


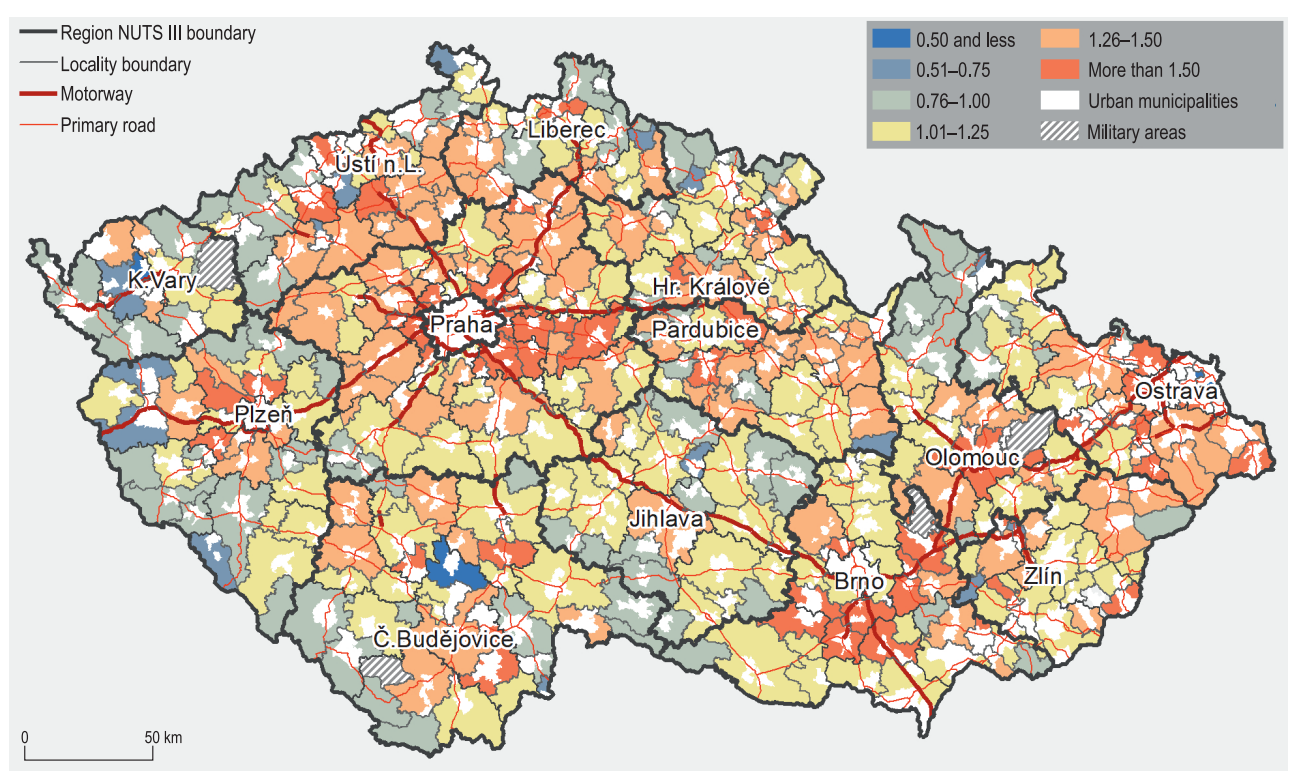

Fig. 3. Change of number of jobs in rural localities of Czechia in the period 2001-2011 (2001=1.00). Source: Czech Statistical Office 2001, 2011; ArcČR 500. Authors' own calculations. Compiled by the authors.

Table 1. Employment development in basic economic sectors in the period 1990-2017 in Czechia

\begin{tabular}{l|r|r|r|r}
\hline \multicolumn{1}{c|}{ Sector } & \multicolumn{1}{c|}{1990} & 2000 & 2010 & 2017 \\
\hline Agriculture, fishing and forestry (NACE A) & 9.9 & 4.9 & 3.1 & 2.8 \\
Mining and quarrying (NACE B) & 3.0 & 1.5 & 1.0 & 0.6 \\
Industry (NACE C-E) & 31.3 & 28.4 & 27.5 & 29.9 \\
Construction (NACE F) & 8.6 & 9.6 & 9.5 & 7.5 \\
Services (NACE G-U) & 47.2 & 55.6 & 58.6 & 58.4 \\
Not found & 0.0 & 0.0 & 0.3 & 0.8 \\
\hline
\end{tabular}

Source: Own calculation based on the Czech Statistical Office 2013, 2018a, 2018c.

\section{Models of rural winners and losers of the post-socialist economic restructuring}

Based on the transformation of the rural economic orientation and performance, six basic models of rural winning and losing localities can be defined regarding the development of number of jobs during the period 1991-2011 (Figure 4).

These models demonstrate key processes and transformations shaping the most (un) successful rural localities (for their overview, see Table 2) based on the development of number of jobs. These localities are manifestations of distinctive and relatively dominant economic processes which constructed Czech rural space during the post-socialist period. As they are just ideal models, they don't have their real spatial anchoring in the map - authors are aware that rural localities are always influenced by specific combinations of multifaceted economic processes. That's why examples in the map below (Figure 5) point to the localities which are close to the suggested models. Moreover, we don't have the ambition to cover the whole area of Czechia - due to the 


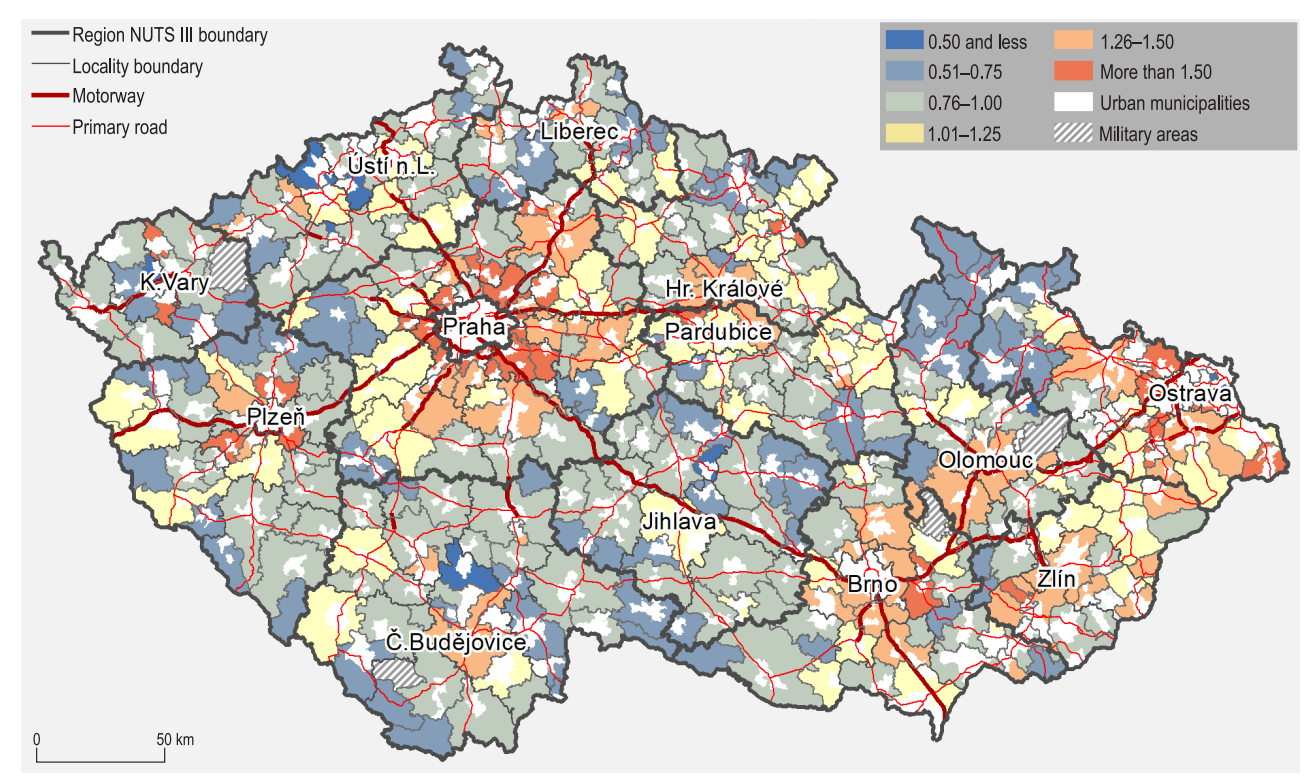

Fig. 4. Change of number of jobs in rural localities of Czechia in the period 1991-2011 (1991=1.00). Source: Federal Statistical Office 1993; Czech Statistical Office 2011; ArcČR 500. Authors' own calculations. Compiled by the authors.

exclusive focus on rural winners and losers, we haven't developed special models for localities formed by other, spatially less important processes as these processes first, didn't formed the winning and losing localities and second, they were limited only to a small number of rural municipalities. For example, in some rural municipalities slight growth of number of jobs has been reported due to the growth of tourism or cross-border shopping tourism (along the border with Germany and Austria) or contrary, the number of jobs slightly decreased as a result of the de-militarization of border areas (especially along the former Iron Curtain border with Bavaria and Austria).

Models A, B and C could be labelled as winners of post-socialist restructuring as their economic transformation can be considered as relatively successful. Model localities D, E and F are those which have suffered economically due to the failed restructuring of local enterprises.

Model A - Globally integrated service-oriented rural localities: Beneficial geographic loca- tion in metropolitan areas (especially in the Prague metropolitan area) along major transport routes is the comparative advantage of these model localities which are largely shaped by commercial suburbanization process. Concentration of plants of transnational companies in logistics and retail can be observed here which enjoy the benefits of their strategic location and large potential market in the core of the metropolitan area. An important factor for the location of logistic firms is also the lack of available land in the city or its high price. These economic activities have brought rapid growth of jobs in localities which used to be strongly dependent on lower number of jobs in agriculture or urban work-commuting during the socialism period. However, these localities (similarly as the following model B) are still dominantly integrated to the urban centre by commuting patterns, as newly created jobs are largely occupied by urban inhabitants and their structure doesn't match with the qualifica- 


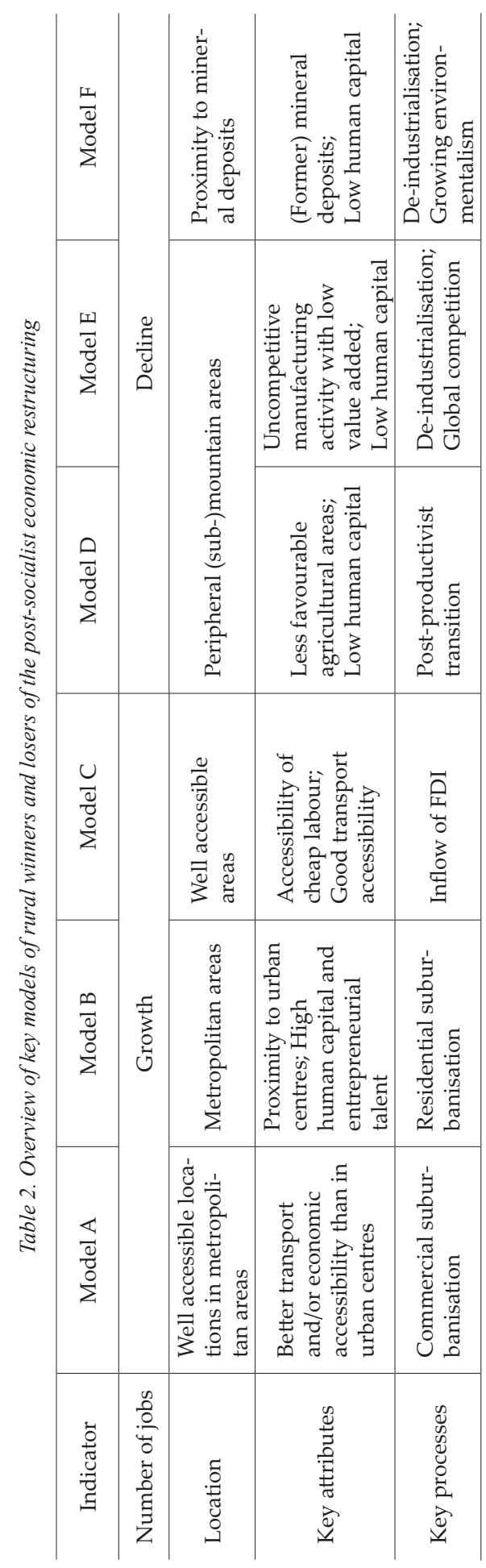

tion of well-educated suburbanizers (SýкORA, L. and OuŘEDníčeK, M. 2007). Moreover, the economic sustainability of these jobs (due to their dependence on decision-making situated abroad) as well as their quality (in terms of average salaries) is disputable.

Model B - Entrepreneurial rural localities: The significant growth of jobs in suburban rural localities of larger urban centres (Prague, Brno, Ostrava and Plzeň) can be explained also by the overall development of small business activity in services driven by well-educated urban newcomers supporting residential suburbanization process. During the socialist period (similarly as in the case of model A) these localities could have been characterised by low number of jobs (mostly in agriculture) and high intensity of work-commuting. New entrepreneurs use constantly growing metropolitan market as its population continues to grow and requires higher capacity of local commercial and public services which further generate new jobs. Also, newcomers offer knowledge intensive business services with high value-added with focus on larger than local market. Overall, these rural localities are characterized by a diversified economy of high local origin and control.

Model C - Industrialised rural localities: In contrast to the previous two service-oriented localities, the economic success of these model localities (situated in well accessible locations with accessible cheap workforce) is based on manufacturing (very often automotive industry). These localities have been a target of rural industrialisation process driven both by FDI and by a successful transformation of former socialist companies. Local economies may be structured by one dominant manufacturing company, cluster of larger manufacturing companies within one industrial park or more diffused cluster of many SMEs. Anyway, their contribution to local development depends on the type of the economic activity and embeddedness of the business activity in the local entrepreneurial milieu. Similarly, as in the case of the A-model localities, their vulnerability might 


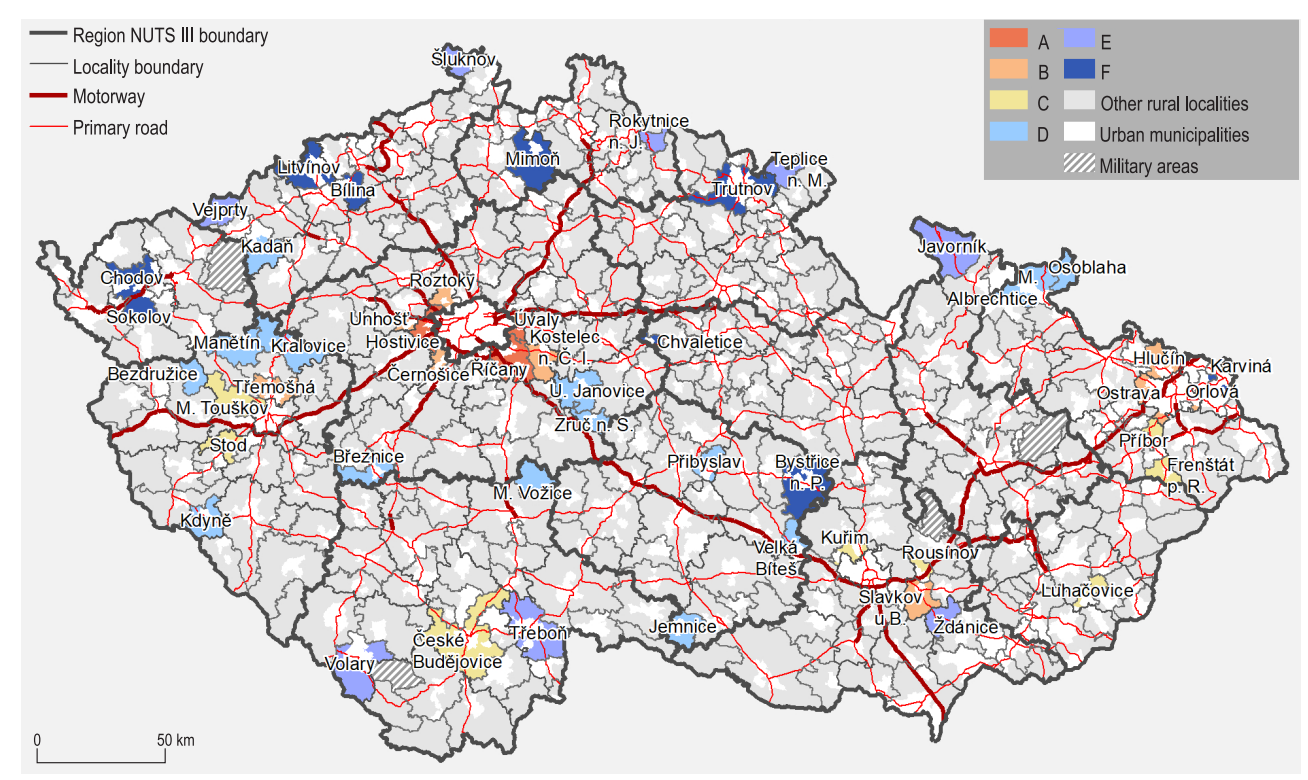

Fig. 5. Overview map of close-to-model examples of winning and losing rural localities of Czechia. Source: Arč̌R 500, compiled by authors.

be higher due to their dependence on one dominant employer or foreign ownership of local branch plant.

Model D - Post-productivist rural localities: These localities are situated in the (sub-) mountain and peripheral areas of Czechia. The decline of agricultural production and consequent job loss was, of course, a national matter, but in these areas the impact of this process was indeed intensive. Rise of the neoliberal regime and consequent reduction of subsidies to agriculture combined with the growing demand for a better environment in this environmentally sensitive landscape have, thus, significantly affected the ability of newly transformed farms to sustain jobs. Due to their peripheral location (also in terms of the quality of human resources - BERNARD, J. and SIMON, M. 2017) these localities have been not able to create new start-ups or attract external investment.

Model E - Deindustrialised rural localities: Unsuccessful transformation of local manufacturing enterprises was another reason of rapid decline in jobs number in these localities. Enterprises in old industries (glass, ceramic, textile) as well as in the wood-processing, metal-working and electromechanical industries appeared as less competitive on the global market. Large decrease in the number of jobs was recorded mainly in the northern part of Czechia which enjoyed rapid prosperity growth during the first waves of the industrial revolution. Similarly to the Post-productivist localities, their isolated location and low human capital of these localities made it impossible to compensate the job loss.

Model F-Post-mining and energy-producing rural localities: Rural localities which were until recently dependent on mining and energy industry could be labelled as absolute losers of post-socialist economic restructuring. These localities were economically dependent on labour-intensive lignite and coal mining, ores extraction (in Czech case especially uranium) and electricity generation (based on burning of coal or lignite). The desire of the socialist state for its self-sufficiency 
in each aspects of economy led to the mining and extraction of raw materials even though their deposits were poor both in terms of quantity and quality of extracted materials. Mining in some localities was maintained by high state subsidies which, similarly as in the case of agriculture, were stopped after the revolution. Another reason for the job loss was also growing work productivity related to the technological modernization of mines or power stations.

\section{Conclusions}

Despite relatively good economic performance of Czech rural localities during the second decade of the post-socialist restructuring, in no way this success has been distributed equally throughout the rural space. Some rural localities which can be labelled as winners (based on our models Globally integrated service oriented, Entrepreneurial and Industrialised rural localities) enjoyed economic growth whereas other localities (Post-productivist, De-industrialised and Post-mining and energy producing rural localities) struggle with economic decline. From this point of view, (de-)industrialisation process can serve as a good example of this highly unequal spatial development. Well accessible rural winners registered growth of number of jobs in modern industries such as automotive contrary to more isolated rural localities which simultaneously suffered from the fall of traditional old industries.

Winning rural localities enjoy the effects of the 'borrowed performance' as they registered rapid growth of employment opportunities both of local (created by entrepreneurial individuals) and extra-local or even global (driven by inflow of FDI especially in services and in manufacturing) origin. From this point of view, urban proximity and/or location along the main transportation axes seems to be a very important factor influencing the ways of rural economic restructuring. On the other hand, the success of Industrialised rural localities may not be permanent. Their one-way orientation on foreign investors is risky, as they are dependent on the managerial decisions of the controlling headquarters situated in foreign countries. Contrary, economies of Post-productivist and Post-mining and energy-producing rural localities suffered from the retreat of the state from the economy during the 1990s which started a vicious circle further reinforced by the brain drain and following weakening of entrepreneurial capacities of local people.

Our analysis didn't prove an important role of tourism for post-socialist rural economies despite the fact that this economic activity is very often perceived as a panacea for local economic problems. Only very small number of rural municipalities in the most attractive locations of national parks evidenced a growth in number of jobs. However, in the context of other CEE countries with higher mountain ranges (High Tatras, Carpathian Mountains and other mountain ranges of the Balkan Peninsula) the results might be different. Similarly, the model of Deindustrialised rural localities might not appear in other countries with different histories of industrialisation than in Czechia and the existence of the Industrialised rural localities is dependent on the overall ability of a given country to attract foreign FDI.

This last remark brings us to the topic of urban-rural shift in employment which has been proved by our analysis for Czechia. This process signalises, first, that it is not correct to consider rural space simply as space where jobs disappear - it is necessary to be aware of the diverse character of rural economies. Second, it confirms the fact, that agriculture is no more the backbone of economies (Terluin, I.J. 2003) even of the most rural regions of Czechia and probably some other post-socialist countries. It is no more possible to view rural economy or rural development through the lenses of agriculture (HrušKa, V. et al. 2015).

Moreover, this new perspective opens up space for rural geographers of the CEE countries to switch to new (albeit in Western 
rural geographies relatively well-established) research topics. This study can serve as a point of departure for studies focusing on rural entrepreneurship, entrepreneurial rural in-migration, branch-plant rural economies, 'old industrial rural areas' (HRUšKA, V. 2018) and similar topics with the whole array of implications for rural development policies and everyday lives of rural people.

Acknowledgements: Vladan HrušKa would like to thank the European Union, European Social Fund and the Ministry of Education, Youth and Sports of the Czech Republic for the financial support of this paper (Project Smart City - Smart Region - Smart Community - CZ.02.1.01/0.0/0.0/17_048/0007435).

\section{REFERENCES}

Alonso, W. 1973. Urban zero population growth. Daedalus 109. 191-206.

ArcČR 500. 2016. Digital geographical database 1:500 000. Arcdata Praha, ZÚ, CSUU, Praha. Available at https://www.arcdata.cz/produkty/geograficka-data/arccr-500

Atterton, J., Bryden, J. and Johnson, T.G. 2012. Rural economic transformation in the UK and US. In Rural transformations and rural policies in the US and UK. Eds.: Shucksmith, M., Brown, D.L., Shortall, S., Verguns, J. and Warner, M.E., London, Routledge, 117-137.

Ballas, D., Kalogeresis, T. and Labrianidis, L. 2003. A comparative study of typologies for rural areas in Europe. In Peripheries, Centres, and Spatial Development in the New Europe. $43^{\text {rd }}$ Congress of the European Regional Science Association, Jyväskylä, 27-30 August 2003. Finland. ERSA Proceedings, Vol 4. Leeds, University of Leeds.

BAŃsKI, J. and MAZUR, M. 2016. Classification of rural areas in Poland as an instrument of territorial policy. Land Use Policy 54. 1-17.

BAšEK, V. 2010. České zemědělství šest let po vstupu do Evropské unie (Czech agriculture six years after the accession to the EU). Praha, Ústav zemědělské ekonomiky a informací.

Baum, S., Trapp, C. and Weingarten, P. 2004. Typology of rural areas in the CEE new Member States. $87^{\text {th }}$ EAAE-Seminar. Assessing rural development of the CAP. IAMO Discusion Papers 72.

Beluszky, P. and Sikos, T.T. 2008. Changing village-typology of rural settlements in Hungary at the beginning of the third millennium. Discussion Papers 66. Ed.: Lux, G., Pécs, Centre for Regional Studies of Hungarian Academy of Sciences. Available at
https://discussionpapers.rkk.hu/index.php/DP/ article/view/2405

Bernard, J. 2012. Prostorové vzorce rozvinutosti venkovských obcí Česka (Spatial patterns of development of Czech rural municipalities). Geografie 117. (1): 72-94.

Bernard, J. and Šimon, M. 2017. Vnitřní periferie v Česku: Multidimenzionalita sociálního vyloučení ve venkovských oblastech (Inner peripheries in Czechia: Multi-dimensionality of social exclusion in rural areas). Sociologický časopis/Czech Sociological Review 53. (1): 3-28.

Bičík, I. and JANČÁK, V. 2005. Transformační Procesy v Českém Zemědělstuí po Roce 1990 (Transformation Processes in Czech Agriculture since 1990). Praha, Katedra sociální geografie a regionálního rozvoje Př́rodovědecké fakulty Univerzity Karlovy.

Bisnode Albertina Database. Version 2018. Praha, Bisnode. Bogdanov, N., Meredith, D. and Efstratoglou, S. 2008. A typology of rural areas in Serbia. Ekonomski Anali / Economic Annals 53. (177): 7-29.

BRown, D.L. 2002. Migration and community: Social networks in a multilevel world. Rural Sociology 67. (1): 1-23.

BRUNori, G. and Rossi, A. 2007. Differentiating countryside: Social representations and governance patterns in rural areas with high social density: The case of Chianti, Italy. Journal of Rural Studies 23. (2): 183-205.

Burger, M.J., Meijers, E.J., Hoogerbrugge, M.M. and TRESSERRA, J.M. 2015. Borrowed size, agglomeration shadows and cultural amenities in North-West Europe. European Planning Studies 23. (6): 1090-1109. ChromÝ, P., JančÁK, V., Marada, M. and HavlíčeK, T. 2011. Venkov - žitý prostor: regionální diferenciace percepce venkova představiteli venkovských obcí v Česku (Rural - lived space: regional differentiation of perception of 'rural' by representatives of rural municipalities in Czechia). Geografie 116. (1): 23-45.

Coe, N.M., Kelly, P.F. and Yeung, H.W.C. 2013. Economic Geography: A Contemporary Introduction. New York, Wiley.

Copus, A.K., Hall, C., Barnes, A., Dalton, G., Cook, P., Weingarten, P. and Mcquaid, R. 2006. Study on Employment in Rural Areas. Luxembourg, European Commission, Directorate General for Agriculture.

Czech Statistical Office 2001. Sč́tání lidu, domů a bytů k 1. 3. 2001 (Census on 1 March 2001). Available at http://www.czso.cz/xt/redakce.nsf/i/podrobne udaje_v_publikacich_ze_sldb_2001

Czech Statistical Office 2011. Sčítání lidu, domů a bytio 2011 (Census 2011). Available at http://www.czso. cz/sldb2011/redakce.nsf/i/home

Czech Statistical Office 2013. Územně analytické podklady: Aktuální údaje za všechny obce ČR 2012 (Data for spatial analysis: recent data for municipalities of the CR 2012). Available at http:// 
www.czso.cz/csu/redakce.nsf/i/csu_a_uzemne_analyticke_podklady

Czech Statistical Office 2018a. Historická ročenka národních účtů - 1990 až 2010 (Historial yearbook of national economic data - 1990-2010). Available at https://www.czso.cz/csu/czso/5013-12-n_2012-04

Czech Statistical Office 2018b. Veřejná databáze ČSÚ (Public Database of CSO). Available at https:// vdb.czso.cz/vdbvo2/faces/cs/index.jsf?page=statistiky\#katalog=30853

Czech Statistical Office 2018c. Data pro Místní akční skupiny (MAS) (Data for Local action groups [LAG]). Available at https://www.czso.cz/csu/czso/ data_pro_mistni_akcni_skupiny_mas

Dingsdale, A. 2002. Mapping Modernities: Geographies of Central and Eastern Europe, 1920-2000. London, Routledge.

DostáL, P. 2007. Explaining differentiation in regional development level in the Czech Republic: non-experimental LISREL modelling. In Modelling Natural Environment and Society. Eds.: DostáL, P. and Langhammer, J., Praha, P3K, 257-283.

Federal Statistical Office 1993. Sčítání lidu, domů a bytů k 3. 3. 1991: pramenné dílo (Census on 3 March 1991). Available at https://www.czso.cz/csu/sldb/ pramenne-dilo-1991

Fothergill, S. and Gudgin, G. 1982. Unequal Growth: Urban and Regional Employment Change in the UK. Portsmouth, Heinemann Educational Publishers.

Freshwater, D. 2000. The promotion of employment and economic development. Paper presented at Rural 21 Conference, Potsdam, 4-8 June 2000..

Gkartzios, M. and Scott, M. 2014. Placing housing in rural development: exogenous, endogenous and neo-endogenous approaches. Sociologia Ruralis 54 . (3): 241-265.

Gorlach, K., LošŤÁK, M. and Mooney, P.H. 2008. Agriculture, communities, and new social movements: East European ruralities in the process of restructuring. Journal of Rural Studies 24. (1): 161-171.

HALFACREE, K.H. 1993. Locality and social representation: space, discourse and alternative definitions of the rural. Journal of Rural Studies 9. (1): 23-37.

Halfacree, K.H. 2004. Rethinking rurality. In New Forms of Urbanization: Beyond the Urban-Rural Dichotomy. Eds.: Champion, T. and Graeme, H., Adershot, Ashgate Publishing, 285-304.

Hampl, M. 2005. Geografická Organizace Společnosti v České Republice: Transformační Procesy a Jejich Obecný Kontext (Geographical Organisation of Society in the Czech Republic: Transformation Processes and its General Context). Praha, Charles University, Faculty of Science, Department of Social Geography and Regional Development.

Hampl, M. and Marada, M. 2015. Sociogeografická regionalizace Česka (Socio-geographical regionalisation of Czechia). Geografie 120. (3): 397-421.
HäUfler, V. 1984. Ekonomická Geografie Československa (Economic Geography of Czechoslovakia). Praha, Academia.

Hodge, I. and Monk, S. 2004. The economic diversity of rural England: stylised fallacies and uncertain evidence. Journal of Rural Studies 20. (3): 263-272.

HogGart, K. 1990. Let's do away with rural. Journal of Rural Studies 6. (3): 245-257.

HoLmes, J. 2006. Impulses towards a multifunctional transition in rural Australia: Gaps in the research agenda. Journal of Rural Studies 22. (1): 142-160.

НRAвÁк, J. and KoneČnÝ, O. 2018. Multifunctional agriculture as an integral part of rural development: Spatial concentration and distribution in Czechia. Norsk Geografisk Tidsskrift/Norwegian Journal of Geography 72. (5): 257-272.

HrušKa, V. 2018. Conceptualizing old industrial rural areas. Paper for EURORURAL ' $18.6^{\text {th }}$ Moravian Conference on Rural Research, 3-7 September 2018, Brno.

HrušKa, V., CZAPIEwsKi, K. and KovÁcs, Z. 2015. Rural economic development in the post-agricultural era: policy recommendations. Studia Obszarow Wiejskich / Rural Studies 39. 129-144.

Jucu, I.S. 2016. From state-socialist ambitions of Romanian rural indutrialisation to post-socialist rural de-industrialisation: Two case studies from Romania. Eastern European Countryside 22. (1): 165-195.

KABRDA, J. and JANČÁK, V. 2007. Impact of selected political and institutional factors on Czech agriculture and landscape. Geografie 112. 48-60.

Keeble, D.E. 1980. Industrial decline, regional policy and the urban - rural manufacturing shift in the United Kingdom. Environment and Planning A: Economy and Space 12. (8): 945-962.

Keeble, D.E. and Tyler, P. 1995. Enterprising behaviour and the urban-rural shift. Working Paper 4. ESRC Centre for Business Research. Cambridge, University of Cambridge.

KLusáčEK, P. 2005. Downsizing of butimunious coal mining and the restructuring of steel works and heavy machine engineering in the Ostrava region. Moravian Geographical Reports 13. (2): 3-12.

Koutský, J. 2011. Staré Průmyslové Regiony - Vývojové Tendence, Možnosti Rozvoje (Old Industrial Regions - Development Tendencies and Opportunities). Ústí nad Labem, Univerzita Jana Evangelisty Purkyně.

Kunc, J., Maryášs, J., Tonev, P., Frantál, B., Sinek, T., HaLÁs, M. and ZusKáčová, V. 2013. Časoprostorové Modely Nákupního Chování České Populace (Timespatial Models of Purchasing Behaviour of Czech Population). Brno, MuniPRESS.

Marini, M. and Mooney, P. 2006. Rural economies. In Handbook of Rural Studies. Eds.: CloKe, P., MARsden, T. and Mooney, P., London, SAGE, 91-103.

Mayer, H., Habersetzer, A. and Meili, R. 2016. Rural-urban linkages and sustainable regional development: The role of entrepreneurs in linking 
peripheries and centres. Sustainability 8(8):745. Doi: 10.3390/su8080745

Meijers, E.J. and Burger, M.J. 2017. Stretching the concept of 'borrowed size'. Urban Studies 54. (1): 269-291.

Moseley, J.M. 2003. Rural Development: Principles and Practice. London, SAGE.

MulíčEK, O. and MaĹ́, J. 2019. Moving towards more cohesive and polycentric spatial patterns? Evidence from the Czech Republic. Papers in Regional Science 98. (2): 1177-1194.

Murdoch, J. and Marsden, T. 1994. Reconstituting Rurality: Class, Community and Power in the Development Process. London, UCL Press.

Murdoch, J. and Marsden, T. 1995. The spatialization of politics: local and national actor-spaces in environmental conflict. Transactions of the Institute of British Geographers 20. 368-380.

Murdoch, J., Lowe, P., Ward, N. and Marsden, T. 2003. The differentiated countryside. New York, Routledge.

MusIL, J. and MüLLER, J. 2008. Vnitřní periferie v České republice jako mechanismus sociální exkluze (Inner peripheries in the Czech Republic as a mechanism of social exclusion). Sociologický časopis / Czech Sociological Review 44. (2): 321-348.

North, D. 1998. Rural industrialization. In The Geography of Rural Change. Ed.: Ilbery, B., Essex, Longman, 161-188.

PavlíneK, P. 1998. Privatisation and the regional restructuring of coal mining in the Czech Republic after the collapse of state socialism. In Theorising Transition: the Political Economy of Post-socialist Transformation. Eds.: Pickles, J. and SMith, A., London, Routledge, 218-239.

PavlíneK, P. 2009. Regional development effects of foreign direct investment in Central and Eastern Europe. In Regional Diversity and Local Development in the New Member States. Eds.: BLOKKER, P. and Dalago, B., London, MacMillan, 166-193.

Perger, É., Farkas, J.Z. and Kovács, A.D. 2016. Delimitation and classification of rural areas in Hungary. Romanian Review of Regional Studies 12. (1): 39-50.

Perlín, R., Kučerová, S. and Kučera, Z. 2010. Typologie venkovského prostoru Česka (Typology of rural space of Czechia). Geografie 115. (2): 161-187.

PíšA, J. and HrušKa, V. 2019. Entrepreneurial in-migration and rural development approaches in Czechia: a challenge of integrating local and extra-local in rural planning. Geographia Polonica 92. (3): 347-363.

PospěCH, P. 2014. Discursive no man's land: Analysing the discourse of the rural in the transitional Czech Republic. Journal of Rural Studies 32. (1): 96-107.

Rey, V. and Bachvarov, M. 1998. Rural settlements in transition - agricultural and countryside crisis in the Central-Eastern Europe. GeoJournal 44. (4): 345-353.

Scholz, J. 2009. Rural Regions in Europe - a New Typology Based on Regional Development Potentials. RUFUS discussion paper 2010-4. Available at http:// www.rufus-eu.de

SwaIn, N. 1996. Rural employment and rural unemployment in the post socialist countryside. Eastern European Countryside 2. 5-16.

SýKorA, L. and OuřEDNíčEK, M. 2007. Sprawling post-communist metropolis: Commercial and residential suburbanisation in Prague and Brno, the Czech Republic. In Employment deconcentration in European metropolitan areas. Eds.: RAzIN, E., DIJST, M. and VÁzquez, C., Dordrecht, Springer, 209-233.

SyNEK, M. 2004. Transformace, restrukturalizace, revitalizace (Transformation, restructuring, revitalisation). Acta Oeconomica Pragensia 3. 170-195. Available at https://doi.org/10.18267/j.aop.266

Szczyrba, Z. 2000. Venkovský obchod v CR v podmínkách ekonomické transformace (Rural shops in the CR under the conditions of economic transformation). Urbanismus a územní rozvoj 3. (6): 15-19.

Terluin, I.J. 2003. Differences in economic development in rural regions of advanced countries: an overview and critical analysis of theories. Journal of Rural Studies 19. (3): 327-344.

TuRnock, D. 1998. Privatization in Rural Eastern Europe: the Process of Restitution and Restructuring. Cheltenham, Edward Elgar.

TuRnock, D. 2000. Globalisation: regional and rural development in Eastern Europe. Prace Geograficzne 106. 7-34.

Van der Ploeg, J.D., Van Broekhuizen, R.E., Brunori, G., Sonnino, R., Knickel, K., Tisenkopfs, T. and Oostindië, H.A. 2008. Towards a framework for understanding regional rural development. In Unfolding webs: the dynamics of regional rural development. Eds.: VAN DER PLOEG, J.D. and MARsden, T., Assen, Van Gorcum, 1-28.

VěžNík, A. 2002. Regionale geographische Aspekten der Transformation der Landwirtschaft in der Tschechischen Republik. Europa Regional 10. 177-189.

Weingarten, P., Neumeier, S., Copus, A., Psaltopoulos, D., Skuras, D., Balamou, E. and RATINGER, T. 2010. Building a Typology of European Rural Areas for the Spatial Impact Assessment of Policies (TERA-SIAP). Luxembourg, European Commission.

WiLson, G. 2010. Multifunctional 'quality' and rural community resilience. Transactions of the Institute of British Geographers 35. (3): 364-381.

Woods, M. 2005. Rural Geography: Processes Responses and Experiences in Rural Restructuring. London, SAGE.

Woods, M. 2013. Regions engaging globalization: A typology of regional responses in rural Europe. 
Journal of Rural and Community Development 8. (3): 113-126.

ŽENKA, J. and SLACH, O. 2018. How do various types of regions attract creative industries? Comparison of metropolitan, old industrial and rural regions in Czechia. Hungarian Geographical Bulletin 67. (3): 239-257.

Ženka, J., Novotný J., Slach, O. and KvětoŇ, V. 2015. Industrial specialization and economic performance: A case of Czech microregions. Norsk Geografisk Tidsskrift / Norwegian Journal of Geography 69. (2): 67-79.
Ženka, J., Slach, O. and Sopkuliak, A. 2017. Typologie českých nemetropolitních regionů z hlediska faktorů, mechanismů a aktérů regionálního rozvoje (Typology of Czech non-metropolitan regions based on factors, mechanisms and actors of regional development). Geografie 122. (3): 281-309.

Žoncová, M. 2018. Evaluation of the diversification of rural landscape in Slovakia after 1989 with a focus on the built-up area of municipalities: a case study of Podhájska municipality. Hungarian Geographical Bulletin 67. (2): 143-158. 
